\title{
Gully erosion as a natural and human-induced hazard
}

\author{
Ion Ionita $^{1} \cdot$ Michael A. Fullen ${ }^{2} \cdot$ Wojciech Zgłobicki ${ }^{3} \cdot$ \\ Jean Poesen ${ }^{4}$
}

(C) The Author(s) 2015. This article is published with open access at Springerlink.com

Gully erosion is an important environmental threat throughout the world and affects multiple soil and land functions. There is ample physical evidence of intense gully erosion occurring at various times in the past in different parts of the world. Gullies are one of the few sources of morphological evidence in the landscape of past phases of intense soil erosion, reflecting the impact of environmental change (especially due to interactions between geomorphological features, changes in land use and extreme climatic events).

Gully erosion represents a major sediment source, although gully channels often occupy $<5 \%$ of the area of a catchment. The development of gullies increases run-off and sediment connectivity in the landscape, hence increasing the risk of flooding and reservoir sedimentation (Verstraeten and Poesen 1999; Poesen et al. 2003). Assessing interactions between environmental change and land degradation is a key issue for environmental scientists, land managers and policy-makers.

\footnotetext{
Wojciech Zgłobicki

wojciech.zglobicki@poczta.umcs.lublin.pl

Ion Ionita

ion.ionita72@yahoo.com

Michael A. Fullen

m.fullen@wlv.ac.uk

Jean Poesen

jean.poesen@ees.kuleuven.be

1 Department of Geography, Faculty of Geography and Geology, “Alexandru Ioan Cuza” University of Iaşi, Carol I Blvd., No. 20A, 700505 Iasi, Romania

2 Faculty of Science and Engineering, The University of Wolverhampton, Wolverhampton WV1 1LY, UK

3 Faculty of Earth Sciences and Spatial Management, University of Maria Curie-Skłodowska, Krasnicka 2CD, 20-718 Lublin, Poland

4 Division of Geography and Tourism, Department of Earth and Environmental Sciences, KU Leuven, Celestijnenlaan 200 E, 3001 Heverlee, Belgium
} 
Over recent decades, significant progress has been made in understanding gully erosion, its controlling factors and associated processes. However, many research questions remain, including gullying mechanisms, human impacts on gully erosion and gully control measures. These questions pose major challenges to the scientific community (Poesen 2011). Gully erosion is a potentially lethal geomorphological process and thus constitutes a major threat to life and property. Hence, geomorphologists can play vital roles in decreasing the threats posed by gully erosion.

Gullying is one of many natural processes that shape the surface of the earth and represents a manifestation of catchment instability. It is only when gullies threaten humankind that they represent a hazard. In the loess regions of Europe, Asia and America, for example, gully erosion might be the most important geomorphic natural hazard. Under these circumstances, geomorphologists face major challenges in making society aware of the impacts of gully erosion.

There are two generally accepted definitions of "hazard." The first refers to a potentially damaging process or situation (such as a landslide or gully). The second definition is more technical and refers to both processes and the probability of occurrence in a unit of time of a given magnitude event (Crozier and Glade 2005). However, population pressure and specific human activities (such as deforestation, improper land use and agricultural practices) have generally increased land degradation and particularly the hazard of gully erosion. From this perspective, gully erosion hazards could be natural, human-induced or both. Some studies emphasized that phases of gully erosion in historical periods were directly related to intensive agricultural land use and more erosive rains (Dotterweich 2008, 2012; Dotterweich et al. 2012; Avni 2008).

Gully erosion causes numerous environmental and socio-economic consequences, and most of them are negative (Poesen et al. 2003; Valentin et al. 2005; Marzolff et al. 2011; Ionita 2011). The initiation and development of both ephemeral and permanent gullies can be regarded as an indicator of land degradation (Poesen et al. 2006; Boardman et al. 2003;

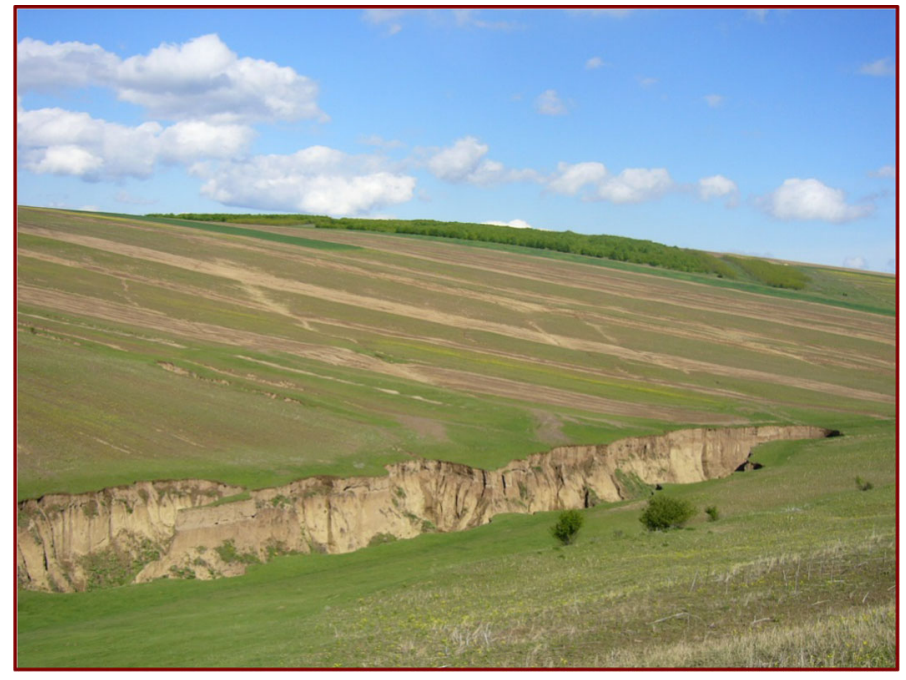

Fig. 1 Valcioaia gully in the Falciu Hills of eastern Romania (10 May 2005). Mean depth is $11 \mathrm{~m}$, and mean width is $17 \mathrm{~m}$ at $20-25 \mathrm{~m}$ downslope from the headcut 
Schuler et al. 2006). Gully development decreases the extent of agricultural land, can decrease farm productivity by incision into land and/or depleting soil resources and can thus decrease crop yields ( $\mathrm{Li}$ et al. 2004; Zgłobicki et al. 2015; Ionita 2006; Ionita et al. 2006; Solé-Benet 2006). Negative economic effects of gully erosion have been reported in numerous case studies (e.g. Kuhlman et al. 2010; Moges and Holden 2008; Yitbarek et al. 2012; Frankl et al. 2013).

This Special Issue comprises 14 papers, most of which were presented at the "6th International Symposium on Gully Erosion in a Changing World (6th ISGE)." This Symposium continued the sequence of successful meetings held in Leuven (Belgium, 2000), Chengdu (China, 2002), Oxford (USA, 2004), Pamplona (Spain, 2007) and Lublin (Poland, 2010). The 6th ISGE, hosted by the "Alexandru Ioan Cuza" University of Iaşi (Romania) from 6 to 12 May 2013, brought together over 50 scientists from all continents to discuss the latest advancements and challenges in gully erosion research. The objectives of the Symposium were to communicate exciting scientific developments, to identify current gaps in knowledge and to discuss ways in which soils and land can be better managed to meet the challenges of protecting the environment against the impacts of climate change and increased human-induced pressure. Two field excursions illustrated various aspects of severe gully erosion in the Moldavian Plateau of East Romania (Figs. 1, 2).

Since the order of papers is logical, we decided not to formally divide the Special Issue into sections. The Volume begins with a paper by Bennett et al. who describe the emergence, persistence and organization of rill networks within an experimental flume. The authors tackle an important research question concerning morphometric constraints in gully formation and its spatio-temporal dynamics. Then, the paper by Maerker and Zakerinejad tries to integrate different approaches (i.e. use of remote sensing techniques and models) for estimating soil loss due to rill and inter-rill erosion with a stochastic method for predicting "gullied" soils, in an area subjected to severe erosion in south-west Iran. The

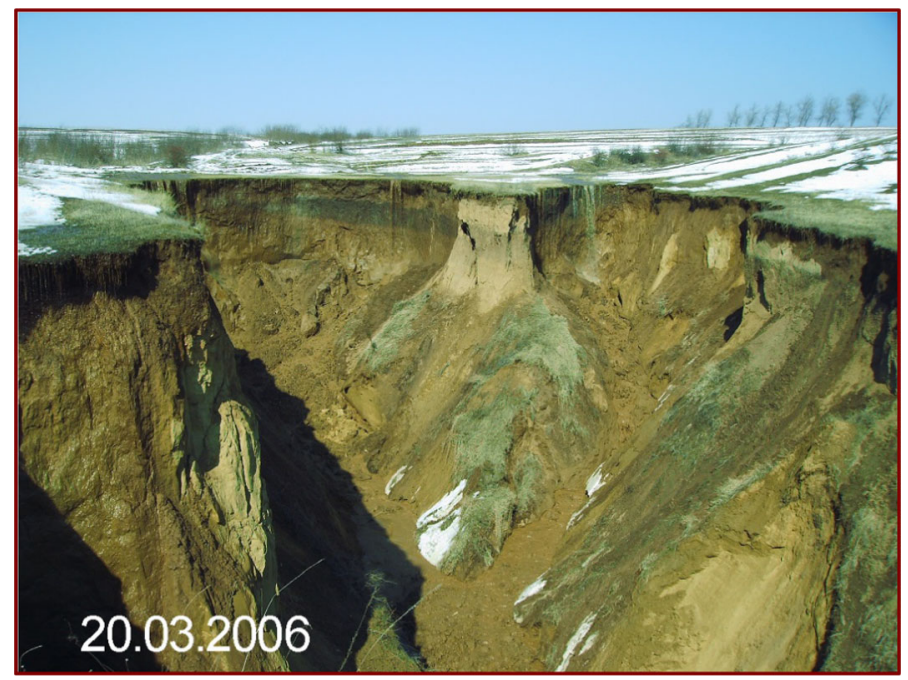

Fig. 2 Puriceni-Bahnari active gully head during snow-melt on 20 March 2006. Mean gully depth is $12.4 \mathrm{~m}$, and mean width is circa $21 \mathrm{~m}$ downslope from the bifurcation 
next paper by Torri et al. contributes to an important ongoing discussion about the definition and interpretation of slope-area thresholds for gully initiation. The establishment of such thresholds is a widespread technique to compare gully initiation under varied land use, climatic and other environmental conditions and represents a promising tool for models aiming to predict gully initiation or erosion. Vergari proposed a new tool to evaluate soil erosion hazard in a severe gullied area (calanchi or badlands) of central Italy. Momm et al. offer an automated methodology to enable detailed monitoring, in both space and time, of the width of eroded channels in laboratory conditions. Based on long-term field measurements and associated time series maps, Ionita et al. discuss chronosequences of gully development in eastern Romania. Here, gully systems have been mainly initiated by human activities and often subsequently trigger landslides. The paper by Kociuba et al. provides information on landscape dynamics and associated hazards, by using terrestrial laser scanning (TLS) and conventional survey approaches in the loess area of south-east Poland. Perhaps surprisingly, Zgłobicki et al. illustrate that these gullies also provide interesting opportunities for educational purposes, as forested gully systems form attractive geo-touristic sites. Su et al. examine the effects of land cover on gully morphodynamics in a dry-hot region of Yunnan Province, south-west China. They manipulated conditions in a controlled in situ field experiment and quantified erosion processes and rates that are hard to observe in nature. The paper by Moeyersons et al. sheds new light on hydrological processes controlling the development of mega-gullies from urbanized areas in the rapidly growing cities of developing countries in tropical climates. Maerker et al. assess gully erosion dynamics in northern Tanzania using improved digital elevation models (DEMs) and demonstrate the utility of publically accessible data (i.e. Google Earth) in scientific research for areas where there are no other available data or where the amount of data is limited. Jurchescu and Grecu show that spatial scale dependence represents an open research topic and this is important for both the scientific community working on models of gully erosion susceptibility assessment and for decision-makers. Gómez-Gutiérrez et al. make a methodological contribution to gully studies by focusing on cause-effect relationships between the considered variables. Unfortunately, due to an involuntary error, the paper by Guerra et al. has already been published in another NHAZ volume of 2015. However, it is considered as being part of this Special Issue as mentioned in the Erratum and investigates gully control using biological geotextiles in Maranhão State, north-east Brazil.

Acknowledgments We gratefully acknowledge the advice and time given by the 30 invited referees of individual papers. They are: Sean Bennett (Buffalo, USA), Charles Bielders (Louvain, Belgium), Paolo Billi (Ferrara, Italy), Antonina Capra (Reggio Calabria, Italy), Javier Casali (Navarra, Spain), Carmen Paz Castro Correa (Santiago, Chile), Michael J. Daniels (Denver, USA), Markus Dotterweich (Mainz, Germany), Amaury Frankl (Ghent, Belgium), Leszek Gawrysiak (Lublin, Poland), Antonio Guerra (Rio de Janeiro, Brazil), Álvaro Gómez-Gutiérrez (Extremadura, Spain), Ana Lucia (Bolzano, Italy), Michael Maerker (Tübingen, Germany), Irene Marzolff (Frankfurt, Germany), Piotr Migoń (Wrocław, Poland), Henrique Momm (Tennessee, USA), Maurizio del Monte (Rome, Italy), Juan Francisco Martinez Murillo (Malaga, Spain), Jean Poesen (Leuven, Belgium), Jerzy Rejman (Lublin, Poland), Ivano Rellini (Genoa, Italy), Estela Nadal-Romero (Amsterdam, The Netherlands), Edoardo Rotigliano (Palermo, Italy), Jeffrey Shelberg (Queensland, Australia), Jolanta Świechowicz (Kraków, Poland), Dino Torri (Perugia, Italy), Matthias Vanmaercke (Leuven, Belgium), Francesca Vergari (Rome, Italy) and Scott Wilkinson (Canberra, Australia). We also thank Springer-NHAZ, the Publisher of this Special Issue, who accepted our proposal to publish the thematic volume, in particular the Senior Editor, Dr. Petra van Steenberger, the Editor-in-Chief, Professor Thomas Glade, Dr. Sridhar Bhavani and Dr. Stefan van Dijl for their assistance and cooperation in producing the Special Issue. Finally, it is our pleasure to acknowledge the authors for their support in producing manuscripts to be incorporated in the thematic volume. We hope this Special Issue will make a 
significant contribution to the field of gully erosion and become an important scientific volume for those dealing with gully erosion and its consequences.

Open Access This article is distributed under the terms of the Creative Commons Attribution 4.0 International License (http://creativecommons.org/licenses/by/4.0/), which permits unrestricted use, distribution, and reproduction in any medium, provided you give appropriate credit to the original author(s) and the source, provide a link to the Creative Commons license, and indicate if changes were made.

\section{References}

Avni Y (2008) Glacial-interglacial cycles, soil erosion and natural desertification in the Middle East. In: Schmidt J, Cochrane T, Phillips C, Elliot S, Davies T, Basher L (eds) Sediment dynamics in changing environments, vol 325. IAHS Publication, Wallingford, pp 383-390

Boardman J, Parson AJ, Holland R, Holmes PJ, Washington R (2003) Development of badlands and gullies in the Sneeuberg, Great Karoo, South Africa. Catena 50(2-4):165-184

Crozier MJ, Glade T (2005) Landslide hazard and risk: issues, concepts and approach. In: Glade T, Anderson M, Crozier MJ (eds) Landslide hazard and risk. Wiley, Chichester, pp 1-40

Dotterweich M (2008) The history of soil erosion and fluvial deposits in small catchments of Central Europe: deciphering the long term interaction between human and the environment-a review. Geomorphology 101:192-208

Dotterweich M (2012) Past soil erosion in central Europe: human impact and long term effects. In: Bebermeier W, Hebenstreit R, Kaiser E, Krause J (eds), Landscape archaeology conference, eTopi, special vol 3. pp 39-45

Dotterweich M, Rodzik J, Zgłobicki W, Schmitt A, Schmidtchen G, Bork H-R (2012) High resolution gully erosion and sedimentation processes, and land use changes since the Bronze Age and future trajectories in the Kazimierz Dolny area (Nałęczów Plateau, SE-Poland). Catena 95:50-62

Frankl A, Poesen J, Haile Mitiku, Deckers J, Nyssen J (2013) Quantifying long-term changes in gully networks and volumes. Geomorphology 201:254-263

Ionita I (2006) Gully development in the Moldavian Plateau of Romania. Catena 68(2-3):133-140

Ionita I (2011) The human impact on soil erosion and gullying in the Moldavian Plateau, Romania. Landf Anal 17:71-73

Ionita I, Radoane M, Mircea S (2006) 1.15 Romania. In: Boardman J, Poesen J (eds) Soil erosion in Europe. Wiley, Chichester, pp 155-166

Kuhlman T, Reinhard S, Gaaf A (2010) Estimating the costs and benefits of soil conservation in Europe. Land Use Policy 27:22-32

Li Y, Poesen J, Valentin C (2004) Gully erosion under global change. Sichuan Science and Technology Press, Chengdu. ISBN 7-5364-5423-6

Marzolff I, Poesen J, Ries JB (2011) Short to medium-term gully development: human activity and gully erosion variability in selected Spanish gully catchments. Landf Anal 17:111-116

Moges A, Holden MN (2008) Estimating the rate and consequences of gully development, a case study of Umbulo catchment in southern Ethiopia. Land Degrad Dev 19(5):574-586

Poesen J (2011) Challenges in gully erosion research. Landform Analysis 17:5-9

Poesen J, Nachtergaele J, Verstraeten G, Valentin C (2003) Gully erosion and environmental change: importance and research needs. Catena 50(2-4):91-133

Poesen J, Vanwalleghem T, de Vente J, Knapen A, Verstraeten G, Martínez-Casasnovas JA (2006) Gully erosion in Europe. In: Boardman J, Poesen J (eds) Soil erosion in Europe. Wiley, Chichester, pp $515-536$

Schuler J, Kächele H, Müller K, Helming K, Zander P (2006) Economic frame for soil conservation policies. In: Boardman J, Poesen J (eds) Soil erosion in Europe. Wiley, Chichester, pp 791-803

Solé-Benet A (2006) 1.26 Spain. In: Boardman J, Poesen J (eds) Soil erosion in Europe. Wiley, Chichester, pp 311-346

Valentin C, Poesen J, Li Y (2005) Gully erosion: impacts, factors and control. Catena 63(2-3):132-153

Verstraeten G, Poesen J (1999) The nature of small-scale flooding, muddy floods and retention pond sedimentation in central Belgium. Geomorphology 29:275-292

Yitbarek TW, Belliethathan S, Stringer LC (2012) The on-site cost of gully erosion and cost-benefit of gully rehabilitation: a case study in Ethiopia. Land Degrad Dev 23:157-166

Zgłobicki W, Baran-Zgłobicka B, Gawrysiak L, Telecka M (2015) The impact of permanent gullies on present-day land use and agriculture in loess areas (E. Poland). Catena 126:28-36 